\title{
Inheritance of Resistance to Root Lesion Nematode in Red Raspberry
}

\author{
T.C. Vrain, Hugh A. Daubeny, J.W. Hall, R.M. DeYoung, and \\ A.K. Anderson \\ Agriculture Canada, Research Station, 6660 North West Marine Drive, \\ Vancouver, British Columbia V6T 1X2, Canada
}

Additional index words. Rubus idaeus, Rubus strigosus, Pratylenchus penetrans, tolerance

\begin{abstract}
The inheritance of resistance to the root lesion nematode [Pratylenchus penetrans (Cobb) Filip. and Stek.] in red raspberry (Rubus idaeus $\mathbf{L}$.) was studied in a four-member half diallel, involving two resistant genotypes and two susceptible genotypes. Estimates of general and specific combining abilities (GCA and SCA, respectively) were determined for nematode densities in roots alone and soil alone, nematode densities per plant, and plant root and foliage biomass. GCA were significant for nematodes in soil and for root and foliage biomass; SCA were significant for nematodes in the soil and for root biomass. Neither GCA nor SCA was significant for number of nematodes in the roots or per plant.
\end{abstract}

In most regions, the root lesion nematode Pratylenchus penetrans continues to be a major limiting factor in red raspberry production. Nematodes destroy the cortical tissue of functional roots and, therefore, reduce the adsorption of water and nutrients from the soil. Bristow et al. (1980) and Vrain and Daubeny (1986) screened $R$. idaeus and related Rubus genotypes for reactions to the nematode and found evidence of resistance. In this context, resistance is a measure of the effects of the host on nematode reproduction; that is, nonresistant plants allow nematodes to multiply freely, and partially resistant plants support intermediate levels of nematodes. Tolerance describes the amount of injury: tolerant plants show little reduction in growth or biomass, even when heavily infected (Cook and Evans, 1987; Seinhorst, 1967; Trudgill, 1991). Our investigation determined the mode of resistance and tolerance inheritance using two genotypes considered somewhat resistant and two susceptible genotypes as parents (Vrain and Daubeny, 1986). We believe this to be the first report on the inheritance of resistance to this nematode in red raspberry.

\section{Materials and Methods}

Parents with a level of resistance to the nematode were 'Nootka' and a North American red raspberry (Rubus strigosus Michx.) selection designated 'Dalhousie Lake'; parents chosen as susceptible were 'Chilliwack' (previously tested as BC 74-10-81) and 'Chilcotin' (Vrain and Daubeny, 1986). These parents were used in a half diallel crossing system to generate six seedling populations. Each population was represented by 18 to 25

\footnotetext{
Received for publication 14 Apr. 1994. Accepted for publication 8 July 1994 . Use of trade names does not imply endorsement of the products named nor criticism of similar ones not named. The cost of publishing this paper was defrayed in part by the payment of page charges. Under postal regulations, this paper therefore must be hereby marked advertisement solely to indicate this fact.
}

seedlings. The seedlings were grown in a sterile peat-perlite mixture (Metromix; W.R. Grace and Co., Ajax, Ont., Canada) supplemented with $10 \mathrm{~N}-52 \mathrm{P}-10 \mathrm{~K}$ fertilizer for 6 months before beginning the study. Plants of parent genotypes were produced from root cuttings taken from field-grown plants and placed into flats of steam-pasteurized, greenhouse soil (Vrain and Daubeny, 1986). Shoots emerging from the root cuttings were removed when they were $5 \mathrm{~cm}$ tall, and the etiolated end of each was dipped into Stem-Rooting Hormone no. 1 (Plant Products Co., Bramalea, Ont., Canada) and placed into flats of Metromix treated with No-Damp (active ingredient $2.5 \%$ oxine benzoate; Plant Products Co.) to control damping-off. The flats were covered with plastic humidity domes and placed on a germination bed heated to $30 \mathrm{C}$. After $\approx 2$ weeks, by which time roots had developed, plants were placed in individual pots containing $1500 \mathrm{~cm}^{3}$ of steam-pasteurized, greenhouse soil. Subsequently, plants were maintained in a greenhouse at $\approx 21 \mathrm{C}$ with a 16 -h photoperiod until nematode inoculation.

Nematodes were raised on greenhousegrown red raspberry plants propagated as described by Vrain and Daubeny (1986). Four months after inoculation with 5000 nematodes per pot, the plants were cut off at soil level and roots were stored at $10 \mathrm{C}$ for 6 months until the beginning of the experiment. When needed, the infected roots were cut into $\approx 2$-cm-long pieces and thoroughly mixed with the soil. This nematode inoculum soil was calibrated using Baermann pans for nematode extraction (Townshend, 1963) and diluted with pasteurized soil so that there were 80,000 nematodes of all life stages per liter of soil.

The inoculum soil was mixed with steampasteurized, greenhouse soil to give a density of 5000 nematodes per $1500 \mathrm{~cm}^{3}$ soil. Each seedling was rinsed and weighed before being planted in an individual pot. Nine to 13 plants of each parent genotype were treated similarly, with equal numbers of parental genotypes placed into pots containing $1500 \mathrm{~cm}^{3}$ of steam-pasteurized soil. All potted plants were placed in six randomized complete blocks in a greenhouse maintained at ambient temperatures, between 16 and $21 \mathrm{C}$.

Eighteen weeks after inoculation, top and root fresh weights were determined for each plant of the respective parent genotypes, including those not inoculated, and for each seedling. Percent reduction in top and root weight due to nematodes was calculated. Nematode counts in roots were determined from a weighed sample of fine feeder roots $(<1$ $\mathrm{mm}$ in diameter) placed in a mist chamber for 7 days (Seinhorst, 1956). Nematode counts in the soil of each pot were determined using a $50-\mathrm{cm}^{3}$ soil sample placed in a Baermann pan for 7 days (Townshend, 1963).

Nematode counts were transformed using $\log _{10}(x+100)$ for statistical analyses. Analyses of variance of the effects of nematodes on top and root weights of the parent genotypes were performed on nontransformed data using the SAS general linear model procedure (SAS Institute, 1985). Estimates of general and specific combining abilities (GCA and SCA, respectively) in the seedling populations were determined for the following variables: 1 ) top weight of each seedling, 2) root weight of each seedling, 3) number of nematodes in $50 \mathrm{~cm}^{3}$ of soil, 4) number of nematodes per gram of roots, 5) number of nematodes per plant (roots and surrounding soil in each pot). All estimates were calculated using Griffing's (1956) method adapted for unequal numbers of observations (England, 1974). Because the block $\times$ cross interactions were not significant, they were pooled with the residual sums of squares to form the error.

\section{Results and Discussion}

Among the parent genotypes, 'Chilliwack' plants were least affected by $P$. penetrans, as indicated by top and root weights (Table 1). These results suggest that the cultivar is relatively nematode tolerant, despite supporting relatively high populations (Vrain and Daubeny, 1986). This tolerance agrees with field observations in the Pacific Northwest and Germany (Daubeny and Seipp, unpublished). In contrast, 'Chilcotin' plants were the most affected by the nematode, particularly with respect to root weight. This result also agrees with field observations in the Pacific Northwest (Daubeny, unpublished). 'Chilcotin' and 'Chilliwack' were chosen for susceptibility to the nematode, as determined in a previous study (Vrain and Daubeny, 1986). In ourstudy, plants of 'Nootka' and the 'Dalhousie Lake' selection of $R$. strigosus showed greater reductions in top and root weights from nematode inoculations than 'Chilliwack', which suggests that each is less nematode tolerant, despite supporting smaller numbers of nematodes. However, the reductions in 'Dalhousie Lake' might have been related partially to the generally poor vigor shown by plants of the selection. The distribution of each variable was examined for bimodality, which would indicate simple inheritance of nematode resistance. Because we found none, we assumed quantitative inheritance. 
Table 1. Effects of Pratylenchus penetrans on top and root weights of red raspberry cultivars previously classed as resistant (R) and susceptible (S) (Vrain and Daubeny, 1986).

\begin{tabular}{|c|c|c|c|c|c|c|c|c|}
\hline \multirow[b]{2}{*}{ Genotype } & \multirow[b]{2}{*}{ Reaction } & \multicolumn{3}{|c|}{ Top wt (g) } & \multicolumn{3}{|c|}{ Root wt (g) } & \multirow{2}{*}{$\begin{array}{c}\text { Nematodes/ } \\
\text { plant }\left(\text { no. } \times 10^{4}\right)\end{array}$} \\
\hline & & Nontreated $^{\mathrm{z}}$ & Treated & $\%$ Normal & Nontreated & Treated & $\%$ Normal & \\
\hline Chilliwack & $\mathrm{S}$ & 100.2 & 90.0 & 90 & 27.3 & 20.8 & 76 & $8.74 \mathrm{a}^{\mathrm{y}}$ \\
\hline Chilcotin & $\mathrm{S}$ & 71.9 & 35.7 & 50 & 26.1 & 7.8 & 30 & $1.50 \mathrm{c}$ \\
\hline Nootka & $\mathrm{R}$ & 100.6 & 81.8 & 81 & 27.3 & 15.2 & 56 & $3.33 \mathrm{~b}$ \\
\hline Dalhousie Lake & $\mathrm{R}$ & 31.5 & 15.7 & 50 & 15.5 & 8.0 & 51 & $1.47 \mathrm{c}$ \\
\hline SE & & 8.11 & 6.83 & & 2.84 & 2.39 & & 0.177 \\
\hline
\end{tabular}

${ }^{2}$ Nontreated $=$ no nematodes; treated $=$ nematodes.

${ }^{\mathrm{y}}$ Means separated by least significant difference test at $P \leq 0.05$.

The highly significant GCA for top weight and root weight (Table 2) suggests that additive gene action is involved and that either or both measures could be used for selection for nematode tolerance in raspberry breeding programs. Thus, parents could be chosen based on phenotypic performance. Resistance to some important raspberry diseases, including spur blight (Didymella applanata [Neissl] Sacc.), fruit rot (Botrytis cinerea Pers. ex Fr.), cane blight [Leptosphaeria coniothyrium (Fuckel) Sacc.], powdery mildew [Sphaerotheca humili (DC.) Burr], leaf spot (Sphaerulina rubi Demaree \& Wilcox), and Phytophthoraincited root rot (Keep, 1989) also is determined largely by additive gene actions.

The GCA estimate was highly significant for nematode counts in soil but was not significant for either nematodes in roots or nematodes per plant (Table 3 ). The highly significant GCA estimate suggests that additive gene action was involved in reaction as determined by the number of nematodes per $50 \mathrm{~cm}^{3}$ of soil. However, this variable is not considered to be as good a measure of host resistance as the number of nematodes per plant (Cook and Evans, 1987; Seinhorst, 1967). This latter measure represents the sum of the nematodes in the roots and those that have fed, reproduced, and emerged from the roots; these nematodes either remain in the surrounding soil where they do not feed or only graze on root hairs. Measurements of nematode densities in roots and soil are normally variable. This can be due to their clumped mode of distribution and the variable efficiencies of the extraction of different life stages from roots and soil. Possibly, more progenies, with more

Table 2. Effects of Pratylenchus penetrans on top and root weights of six red raspberry progenies with estimates of general and specific combining abilities (GCA ${ }^{\mathrm{z}}$ and SCA, respectively).

\begin{tabular}{|c|c|c|c|c|c|c|c|c|}
\hline & \multicolumn{8}{|c|}{ Cultivar } \\
\hline & \multicolumn{2}{|c|}{ Chilliwack } & \multicolumn{2}{|c|}{ Chilcotin } & \multicolumn{2}{|c|}{ Nootka } & \multicolumn{2}{|c|}{ Dalhousie Lake } \\
\hline & Top & Root & Top & Root & Top & Root & Top & Root \\
\hline Chilliwack & $9.95^{y}$ & -3.71 & & & & & & \\
\hline Chilcotin & -1.15 & -1.20 & -4.17 & 0.02 & & & & \\
\hline Nootka & 1.01 & 2.82 & 0.15 & -1.61 & -0.85 & -0.93 & & \\
\hline Dalhousie Lake & 0.15 & 1.61 & 1.00 & 2.82 & -1.16 & -1.20 & -4.93 & 4.62 \\
\hline Parental effects & & & df & & $\begin{array}{r}\mathrm{T} \\
\text { mear } \\
\end{array}$ & $\begin{array}{l}\text { Nt } \\
\text { uare } \\
7^{* *}\end{array}$ & & $\begin{array}{l}t \text { wt } \\
\text { square }\end{array}$ \\
\hline Additive (GCA) & & & 3 & & 235 & & & $3.45^{* *}$ \\
\hline Nonadditive (SCA) & & & 2 & & & & & $8.26^{* *}$ \\
\hline Error (residual) & & & 140 & & & & & 3.21 \\
\hline
\end{tabular}

${ }^{\mathrm{z}} \mathrm{GCA}$ estimates are arranged diagonally.

${ }^{y_{\mathrm{SE}}}$ for top $\mathrm{GCA}=2.08$ and $\mathrm{SCA}=1.96$; $\mathrm{SE}$ for root $\mathrm{GCA}=0.93$ and $\mathrm{SCA}=0.88$.

Ns, ** Nonsignificant or higly significant at $P \leq 0.01$, respectively.

seedlings in each, would reduce variability and, in doing so, would allow determination of the resistance inheritance mode.

\section{Literature Cited}

Bristow, P.R., B.H. Barritt, and F.D. McElroy. 1980. Reaction of red raspberry clones to root lesion nematode. Acta Hort. 112:39-43.

Cook, R. and K. Evans. 1987. Resistance and tolerance, p. 179-231. In: R.H. Brown and B.R. Kerry (eds.). Principles and practice of nematode control in crops. Academic, Sydney.

England, F. 1974. A general approximate method for fitting additive and specific combining abilities to the diallel cross with unequal numbers of observations in cells. Theor. Applied Genet. 44:378-380.

Griffing, B. 1956. Concept of general and specific combining ability in relation to diallel crossing systems. Austral. J. Biol. Sci. 9:463-493.

Keep, E. 1989. Breeding red raspberry for resistance to diseases and pests. Plant Breeding Rev. 6:245-321.
SAS Institute. 1985. SAS user's guide: Statistics. Version 5th ed. SAS Institute, Cary, N.C.

Seinhorst, J.W. 1956. The quantitative extraction of nematodes from soil. Nematologica 1:249-267.

Seinhorst, J.W. 1967. The relationship between population increase and population density in plant parasitic nematodes. III. Definition of the terms host, host status and resistance. IV. The influence of external conditions on the regulation of population density. Nematologica 13:429-442.

Townshend, J.L. 1963. A modification and evaluation of the apparatus for the Oostenbrink direct cottonwool filter extraction method. Nematologica 9:106-110.

Trudgill, D.L. 1991. Resistance to and tolerance of plant parasitic nematodes in plants. Annu. Rev. Plant Pathol. 29:167-192.

Vrain, T.C. and H.A. Daubeny. 1986. Relative resistance of red raspberry and related genotypes to the root lesion nematode. HortScience 21:14351437.

Table 3. Pratylenchus penetrans resistance in six raspberry progenies with estimates of general and specific combining abilities (GCA ${ }^{z}$ and SCA, respectively) for number of nematodes per gram of roots and $50 \mathrm{~cm}^{3}$ of soil and total number of nematodes per plant.

\begin{tabular}{|c|c|c|c|c|c|c|c|c|c|c|c|c|}
\hline \multirow[b]{4}{*}{ Cultivar } & \multicolumn{12}{|c|}{ Cultivar } \\
\hline & \multicolumn{3}{|c|}{ Chilliwack } & \multicolumn{3}{|c|}{ Chilcotin } & \multicolumn{3}{|c|}{ Nootka } & \multicolumn{3}{|c|}{ Dalhousie Lake } \\
\hline & \multicolumn{3}{|c|}{ No. nematodes per } & \multicolumn{3}{|c|}{ No. nematodes per } & \multicolumn{3}{|c|}{ No. nematodes per } & \multicolumn{3}{|c|}{ No. nematodes per } \\
\hline & $\mathrm{g}$ & $50 \mathrm{~cm}^{3}$ & plant & $\mathrm{g}$ & $50 \mathrm{~cm}^{3}$ & plant & $\mathrm{g}$ & $50 \mathrm{~cm}^{3}$ & plant & $\mathrm{g}$ & $50 \mathrm{~cm}^{3}$ & $\overline{\text { plant }}$ \\
\hline Chilliwack & $0.112^{y}$ & -0.046 & 0.012 & & & & & & & & & \\
\hline Chilcotin & -0.042 & -0.046 & 0.008 & -0.025 & 0.053 & -0.048 & & & & & & \\
\hline Nootka & -0.141 & 0.085 & 0.010 & -0.097 & -0.039 & -0.019 & 0.074 & 0.080 & 0.065 & & & \\
\hline \multirow[t]{2}{*}{ Dalhousie Lake } & -0.097 & -0.039 & -0.019 & -0.141 & 0.085 & 0.010 & 0.042 & -0.046 & 0.008 & -0.068 & -0.087 & -0.029 \\
\hline & & & & \multicolumn{9}{|c|}{ Mean square } \\
\hline \multicolumn{2}{|l|}{ Parental effect } & \multicolumn{2}{|c|}{ df } & \multicolumn{3}{|c|}{ No. nematodes/g of root } & \multicolumn{3}{|c|}{ No. nematodes $/ 50 \mathrm{~cm}^{3}$ soil } & \multicolumn{3}{|c|}{ No. nematodes/plant } \\
\hline Additive (GCA) & & \multicolumn{2}{|c|}{$\overline{3}$} & \multicolumn{3}{|c|}{$0.34^{\text {Ns }}$} & \multicolumn{3}{|c|}{$0.32^{* *}$} & \multicolumn{3}{|c|}{$0.13^{\mathrm{Ns}}$} \\
\hline Nonadditive (SCA) & & \multicolumn{2}{|c|}{2} & \multicolumn{3}{|c|}{$0.12^{\mathrm{Ns}}$} & \multirow{2}{*}{\multicolumn{3}{|c|}{$0.27^{*}$}} & \multicolumn{3}{|c|}{$0.01^{\mathrm{Ns}}$} \\
\hline Error & & \multicolumn{2}{|c|}{140} & \multicolumn{3}{|c|}{1.01} & & & 0.07 & \multicolumn{3}{|c|}{0.06} \\
\hline
\end{tabular}

${ }^{2} \mathrm{GCA}$ estimates are arranged diagonally.

${ }_{\mathrm{S}}^{\mathrm{SE}}$ for no. nematode $/ \mathrm{g} \mathrm{GCA}=0.097$ and $\mathrm{SCA}=0.091 ; \mathrm{sE}$ for no. nematodes $/ 50 \mathrm{~cm}^{3} \mathrm{GCA}=0.033$ and $\mathrm{SCA}=0.03$; se for no. nematodes $/ \mathrm{plant} \mathrm{GCA}=0.03$ and SCA $=0.028$.

NS, *** Nonsignificant or significant at $P \leq 0.05$ or 0.01 , respectively. 